\title{
SUITABILITY OF SIXTEEN ASPARAGUS CULTIVARS FOR GROWING IN POLISH ENVIRONMENTAL CONDITIONS
}

\author{
Mikołaj KNAFLEWSKI*, Alina KAŁUŻEWICZ, Wenjing CHEN, Anna ZAWORSKA, \\ Włodzimierz KRZESIŃSKI \\ Department of Vegetable Crops, Poznań University of Life Sciences \\ Dąbrowskiego 159, 60-594 Poznań, Poland
}

Received: May 29, 2014; Accepted: October 27, 2014

\begin{abstract}
Green spear yield of 16 asparagus cultivars originating from six countries was assessed from 2011 to 2013. There were considerable differences in total, marketable and early yields between the cultivars. The quality of harvested spears also varied remarkably. On average, the highest mean total and marketable yields from 3 years of investigation came from Dutch cultivars 'Gijnlim' and 'Cumulus' and German cv. 'Mondeo'. The lowest yields were found in New Zealand cultivars 'Pacific Challenger' and 'Pacific 2000'. The greatest mean marketable spear weight was recorded for 'Cumulus', whereas the smallest spear weight was obtained from 'Pacific 2000', 'H666' and 'NJ 953'. Cultivars 'Gijnlim', 'Cumulus' and 'Mondeo' produced the highest early yields, while 'Pacific 2000' and 'Pacific Challenger' produced the lowest.

In order to determine the dependence between summer stalks size of tested cultivars in the preceding year and their yields in the following year, regression equations and their correlation coefficients were estimated. The size of summer stalks was expressed as plant growth index, which was the multiplication of height and total cross-sectional area of summer stalks. There was a significant and positive correlation between plant growth index of tested cultivars and their yields in the next vegetation period. The correlation coefficients between these two parameters amounted to 0.62 and 0.68 in 2011/2012 and 2012/2013, respectively.
\end{abstract}

Key words: Asparagus officinalis, cultivar, yield, growth index

\section{INTRODUCTION}

Asparagus is a well-known and commonly grown vegetable not only in Europe, but also in other parts of the world. China and Peru were the world's biggest asparagus producers in 2012 (FAOSTAT 2014). Cultivation methods of asparagus vary depending on regions and their climatic conditions. Asparagus is grown mainly for green spears in North and South Americas (Benson 2008), while in Europe cultivation of white asparagus is more common. Germany is the greatest asparagus producer in Europe (Knaflewski et al. 2011). The annual asparagus production amount in Poland is around 5000 tons and a major part of it is exported to Germany. Although growing green asparagus is becoming increasingly popular in Poland, its production accounts for only small percentage of total asparagus production (Knaflewski et al. 2011). Asparagus yield, to a great extent, depends on interaction between cultivar characteristics and the climatic conditions. Studies on the suitability of asparagus cultivars grown in different parts of the world have been conducted for more than 30 years within the International Asparagus Cultivar Trial - Nichols (1997), Benson (2002), Jinsong (2002), González (2012). So far, all cultivars grown in Poland come from abroad, mostly from the Netherlands and Germany and some from France and Spain. However, not all foreign-bred cultivars are suitable for the Polish climatic conditions. Therefore, evaluation of yielding of cultivars of different origin in one exper- 
iment seems necessary to get knowledge on their yielding potential in particular growing conditions.

\section{MATERIALS AND METHODS}

\section{Field trial establishment}

A field trial for harvesting green asparagus spears of 16 cultivars was established (Table 1) on the podsolic soil, the arable layer of which was loamy sand underlying sandy loam, in July 2008. A few months before planting $100 \mathrm{~kg} \cdot \mathrm{ha}^{-1}$ of $\mathrm{P}_{2} \mathrm{O}_{5}$, $200 \mathrm{~kg} \cdot \mathrm{ha}^{-1}$ of $\mathrm{K}_{2} \mathrm{O}$ and $1500 \mathrm{~kg} \cdot \mathrm{ha}^{-1}$ of dolomite were applied before soil cultivation. Available macronutrients content before planting in $0.03 \mathrm{~N} \mathrm{CH}_{3} \mathrm{COOH}$ amounted to: $\mathrm{P}-80 \mathrm{mg} \cdot \mathrm{dm}^{-3}, \mathrm{~K}-200 \mathrm{mg} \cdot \mathrm{dm}^{-3}, \mathrm{Mg}-$ $50 \mathrm{mg} \cdot \mathrm{dm}^{-3}$ and $\mathrm{pH}$ of soil/water suspension was 6.5 .

Table 1. Asparagus cultivars included in this study and their origins

\begin{tabular}{lc}
\hline \multicolumn{1}{c}{ Cultivar } & Origin \\
\hline Avalim & \\
White Angel & The Netherlands \\
Cumulus & \\
Ginjlim & \\
\hline Guelph Millennium & Canada \\
HP 149 & \\
\hline Mo 2/12 & Germany \\
Mondeo & \\
Ramires & \\
Rapsody & New Zealand \\
\hline Pacific Challenger & \\
Pacific 2000 & USA \\
\hline NJ 953 & \\
\hline Victor & Italy \\
H 666 & \\
Ercole &
\end{tabular}

Three-month-old greenhouse transplants were planted in the field. Fifteen transplants of each cultivar at a space of $1.8 \times 0.4 \mathrm{~m}$ and a depth of $20 \mathrm{~cm}$ in each plot were planted. The harvest began in 2011 when plants were 4-year-old. The second and third harvests were conducted in 2012 and 2013. Spears were harvested when they reached the height of about $22 \mathrm{~cm}$ above the soil.

\section{Total, marketable and early yield}

The marketable yield obtained until 15th May in each year was considered as the early yield. The sum of Extra Class, Class I and Class II was considered as marketable yield and the sum of marketable and unmarketable yields constituted total yield. Yield of each quality class, early, marketable and total were expressed in $\mathrm{kg} \cdot \mathrm{ha}^{-1}$ while mean spear weight in grams.

\section{Quality classification}

A number of spears, in particular, classes and a fresh weight of spears in each class were determined. Extra class included spears of diameter $>16 \mathrm{~mm}$, with closed, compact heads, straight or very slightly bent. Spears of diameter $>8 \mathrm{~mm}$, with heads compact or slightly loose, slightly bent but the bent radius could not exceed $1 \mathrm{~cm}$ for each $10 \mathrm{~cm}$ bend were counted as Class I. Spears of diameter $>6 \mathrm{~mm}$ with slightly loose heads, strongly crooked with the bent radius smaller than $2 \mathrm{~cm}$ for each $10 \mathrm{~cm}$ bent diameter were classified as Class II. Very thin, hollowed, cracked and extremely bent spears with loose heads were qualified as unmarketable.

\section{Growth index}

For each cultivar, height and diameter of summer stalks of five plants in each plot were measured at the end of the vegetation period in autumn 2011 and 2012. Growth index was calculated by multiplying total cross-sectional area and height of summer stalks. The summer stalk cross-sectional area was calculated using the following formula:

$$
\begin{gathered}
\sum_{i=1}^{n} \pi r_{i}^{2} \\
(r=\text { radius of a summer stalk; } n=\text { number of summer } \\
\text { stalks })
\end{gathered}
$$

\section{Statistical analysis}

A completely randomized block design with five replications was used in the trial.

All yield parameters were analysed by ANOVA and the means were separated by the Newman-Keul's test $5 \%$. For the analyses, the statistical program 'STAT' was applied. Correlation coefficients and regression equations were estimated by Excel Microsoft Corp. 


\section{RESULTS AND DISCUSSION}

\section{Yield and spear quality}

The earliest harvesting was recorded in 2011 and the latest in 2013 (Table 2). The late harvest was caused by very low temperatures in early April 2013 (Table 3). In the first 2 weeks of April in 2013, the average daily air temperature was almost three times lower and the average minimum daily air temperature was 12 times lower than in 2011. Growth of asparagus spears strongly depends on temperature. According to Bouwkamp and Mc Cully (1975), the minimum temperature for the growth of asparagus spears was $4.4^{\circ} \mathrm{C}$, while Blumenfield et al. (1961) found it to be $7.2{ }^{\circ} \mathrm{C}$. It was reported by Nichols and Woolley (1985) that there was a linear correlation between the temperature range from 10 to $30^{\circ} \mathrm{C}$ and the growth of asparagus spears from 1 to $20 \mathrm{~cm}$. The results obtained by Dean (1999) showed that the maximum spear elongation occurred at $30{ }^{\circ} \mathrm{C}\left(0.51 \mathrm{~cm} \cdot \mathrm{h}^{-1}\right)$. Wilson et al. (1999) stated that cultivars differed in their responses to temperature.

Table 2. The beginning and the end of harvest in particular years of the field trial

\begin{tabular}{cccc}
\hline \multirow{2}{*}{ Year } & \multicolumn{3}{c}{ Harvest } \\
\cline { 2 - 4 } & Beginning & End & $\begin{array}{c}\text { Duration } \\
\text { (days) }\end{array}$ \\
\hline 2011 & 21.04 & 2.06 & 42 \\
2012 & 23.04 & 10.06 & 48 \\
2013 & 28.04 & 18.06 & 51 \\
\hline
\end{tabular}

Table 3. Minimal and mean daily air temperature during the first 2 weeks of April and during the whole harvest period from 2011 to 2013

\begin{tabular}{|c|c|c|}
\hline \multirow{3}{*}{ Year } & \multicolumn{2}{|c|}{ Daily air temperature $\left({ }^{\circ} \mathrm{C}\right)$} \\
\hline & Minimal & Mean \\
\hline & \multicolumn{2}{|c|}{ The first two weeks of April } \\
\hline 2011 & 6.1 & 10.2 \\
\hline 2012 & 2.8 & 7.9 \\
\hline \multirow[t]{2}{*}{2013} & 0.5 & 3.5 \\
\hline & \multicolumn{2}{|c|}{ The whole harvest period } \\
\hline 2011 & 8.3 & 14.9 \\
\hline 2012 & 9.7 & 15.6 \\
\hline 2013 & 10.7 & 15.5 \\
\hline
\end{tabular}

The highest total and marketable yields were obtained in cultivars 'Gijnlim', Cumulus' and 'Mondeo'; whereas the lowest in 'Pacific Challenger' and 'Pacific 2000' cultivars (Table 4, Fig. 1). The total yield of 'NJ 953' was also very low. Mulder and Lavrijsen (2008) also reported a very high yielding ability of 'Gijnlim', which reached more than $12000 \mathrm{~kg} \cdot \mathrm{ha}^{-1}$ as early as in the second year of harvest. According to their study, 'Rapsody' (over $10000 \mathrm{~kg} \cdot \mathrm{ha}^{-1}$ ) 'Avalim' and 'NJ 953' (over $9000 \mathrm{~kg} \cdot \mathrm{ha}^{-1}$ ) were characterised by a very high yield. The high yielding ability of 'Gijnlim' was also reported by Paschold et al. (2008) and by Drost (2002). In the study of Rodkiewicz (2011), not only 'Gijnlim', but also other Dutch cultivars 'Backlim', 'Horlim' and 'Thielim' were characterised by very high yielding ability. Zhu et al. (2013) concluded that of 28 asparagus cultivars, 'Gijnlim' gave not only the highest total and marketable yields, but also the highest yield in the Extra class.

Cermeňo et al. (2008) reported that 'NJ 953' and 'Ercole' were among the highest yielding cultivars in Spain. 'NJ 953' was one of the cultivars with the highest marketable yield. High yielding performance of 'NJ 953' was also confirmed by González (2008, 2012) in Chile. However, in our study, 'Ercole' was ranked only as 9th and 'NJ 953' as 14th among 16 cultivars. Araki et al. (2012) found that Dutch cultivars, especially 'Gijnlim' and 'Avalim', produced very high total yields in Japan. Both of them, as well as 'Pacific 2000', gave also a high marketable yield. In our experiment, 'Pacific 2000' gave the lowest total and marketable yields. According to Araki et al. (2012), mean spear weight of 'Gijnlim' and 'Avalim' ranged from 24 to $25 \mathrm{~g}$ while that of 'Pacific 2000' amounted to $17 \mathrm{~g}$. Similar mean spear weights of 'Gijnlim' and 'Avalim' were obtained in our study (Table 4), whereas mean spear weight of 'Pacific 2000' reached only $14 \mathrm{~g}$ and it was even lower than the results reported by Araki et al. (2012). Our study also revealed considerable differences between particular cultivars in the share of marketable yield in the total yield (Table 4). Cultivar 'NJ 953' turned out to have the biggest share of marketable yield in the total yield (78.5\%) of all cultivars whereas 'White Angel' the smallest $(63.1 \%)$. 
Table 4. Total and marketable yields and mean spear weight of 16 asparagus cultivars (mean of 2011-2013)

\begin{tabular}{|c|c|c|c|c|}
\hline \multirow{2}{*}{ Cultivar } & \multicolumn{2}{|c|}{ Yield $\left(\mathrm{kg} \cdot \mathrm{ha}^{-1}\right)$} & \multirow{2}{*}{ Marketable yield (\%) } & \multirow{2}{*}{ Mean spear weight $(\mathrm{g})$} \\
\hline & Total & Marketable & & \\
\hline Gijnlim & $8540 \mathrm{a}^{*}$ & $6340 \mathrm{a}$ & 74.2 & $22.8 \mathrm{~b}-\mathrm{e}$ \\
\hline Cumulus & 8380 a & $5710 \mathrm{ab}$ & 68.1 & $31.1 \mathrm{a}$ \\
\hline Mondeo & $8310 \mathrm{a}$ & $5590 \mathrm{ab}$ & 67.3 & $22.5 \mathrm{~b}-\mathrm{e}$ \\
\hline HP 149 & $7580 \mathrm{ab}$ & $5350 \mathrm{ab}$ & 70.6 & $22.4 \mathrm{c}-\mathrm{e}$ \\
\hline Avalim & $7240 \mathrm{ab}$ & $4980 \mathrm{ab}$ & 68.8 & $25.2 \mathrm{~b}-\mathrm{d}$ \\
\hline Ramires & $7050 \mathrm{a}-\mathrm{c}$ & $5070 \mathrm{ab}$ & 71.9 & $24.2 \mathrm{~b}-\mathrm{d}$ \\
\hline Victor & $6890 \mathrm{a}-\mathrm{c}$ & $5290 \mathrm{ab}$ & 76.8 & $25.8 \mathrm{bc}$ \\
\hline Rapsody & $6450 a-d$ & $4550 \mathrm{a}-\mathrm{c}$ & 70.5 & $22.8 \mathrm{~b}-\mathrm{e}$ \\
\hline Ercole & $6050 \mathrm{a}-\mathrm{d}$ & $4440 \mathrm{a}-\mathrm{c}$ & 73.4 & 19.5 ef \\
\hline Guelph Millennium & $6000 \mathrm{a}-\mathrm{d}$ & $4340 \mathrm{a}-\mathrm{c}$ & 72.3 & $20.2 \mathrm{~d}-\mathrm{f}$ \\
\hline White Angel & $5770 \mathrm{~b}-\mathrm{d}$ & $3640 \mathrm{bc}$ & 63.1 & $22.9 \mathrm{~b}-\mathrm{e}$ \\
\hline Н 666 & $5730 \mathrm{~b}-\mathrm{d}$ & $4250 \mathrm{a}-\mathrm{c}$ & 74.2 & $19.3 \mathrm{ef}$ \\
\hline Mo 2/12 & $5710 \mathrm{~b}-\mathrm{d}$ & $4230 \mathrm{a}-\mathrm{c}$ & 74.1 & $27.2 \mathrm{~b}$ \\
\hline NJ 953 & $5440 \mathrm{~b}-\mathrm{d}$ & $4270 \mathrm{a}-\mathrm{c}$ & 78.5 & $16.0 \mathrm{fg}$ \\
\hline Pacific Challenger & $4510 \mathrm{~cd}$ & 2920 c & 64.7 & $15.0 \mathrm{~g}$ \\
\hline Pacific 2000 & $4210 \mathrm{~d}$ & $2970 \mathrm{c}$ & 70.5 & $14.0 \mathrm{~g}$ \\
\hline
\end{tabular}

*Means followed by the same letter do not differ at $\mathrm{p}=0.05$ according to Newman-Keuls test

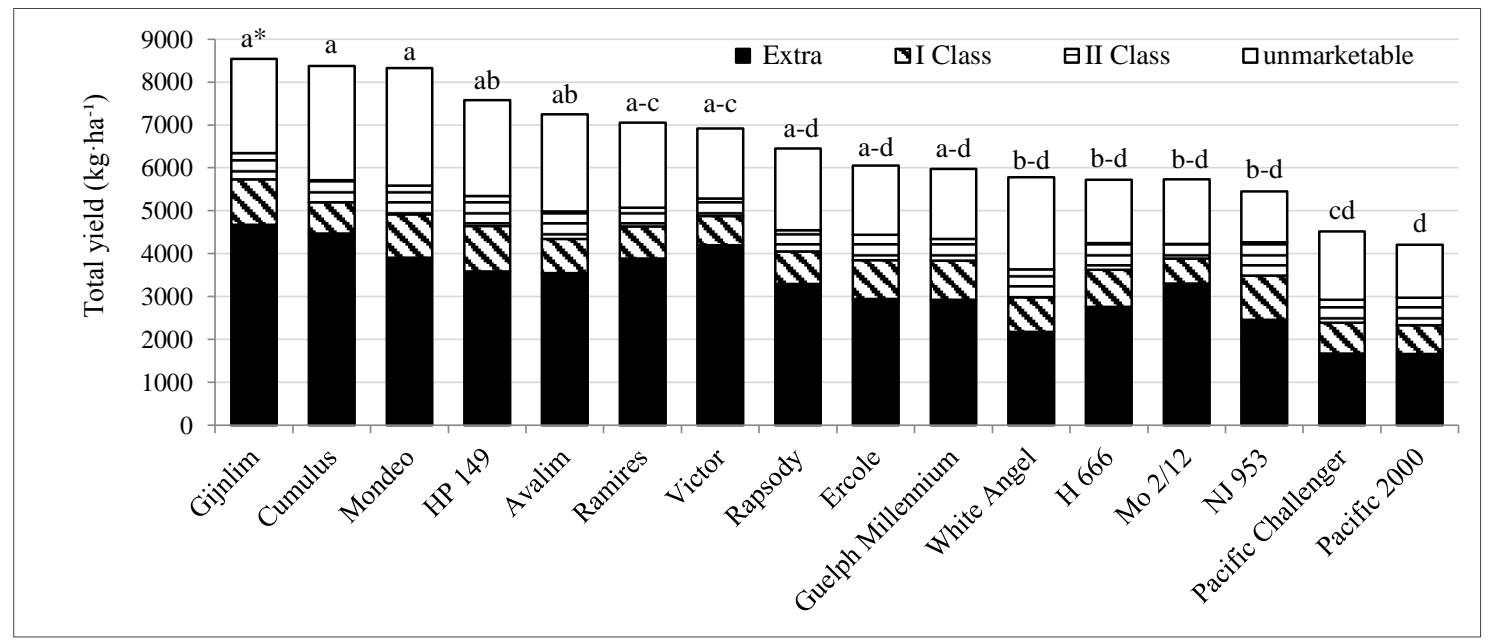

*Means followed by the same letter do not differ at $\mathrm{p}=0.05$ according to Newman-Keuls test

Fig. 1. Yield structure of 16 asparagus cultivars (mean of 2011-2013)

In our experiment, considerable differences in the early yield between particular cultivars were found (Table 5). The highest early yield was observed in 'Gijnlim', while that in 'Cumulus' and 'Mondeo' was slightly lower. Two New Zealand cultivars, 'Pacific Challenger' and 'Pacific 2000' were characterised by the lowest early yield. Earliness of cultivars 'Gijnlim' and 'Mondeo' was also confirmed by Paschold et al. (2008). In their study,
'Gijnlim' and 'Ravel' were the earliest of 14 asparagus cultivars evaluated and they were closely followed by 'Mondeo'. Cultivar 'Rapsody' was described as a mid-early one, which corresponded with the results from our study. In the experiment conducted by Zhu et al. (2013), 'Gijnlim' and 'Hannibal' were the earliest of 28 cultivars. The share of early yield in marketable yield of 'Gijnlim' reached about $56 \%$ in their study, whereas in our study it 
was slightly lower and amounted to 50\%. Conversely, 'Mondeo' had the highest share of early yield in the marketable yield, but 'Mo 2/12' the lowest in our study.

\section{The correlation between plant growth index and} yield

Moon (1976) stated that yield of spears in the next vegetation period strongly depended on the number of summer stalks in the previous year. Knaflewski (1994) stated that from such traits as number, height and weight of stems, their cross sectional area, circumference of the crown area from which stalks emerged; crown circumference was the parameter most correlated with yield.
The dependence between summer stalk size of plants in the preceding year and the yield of spears in the following year was also studied by Araki et al. (2012). Dry weight of summer stalks was found to be highly correlated with the total and marketable yields and mean spear weight and the correlation coefficients amounted to $0.713,0.586$ and 0.544 , respectively.

In this study, 'Mondeo', 'Ramires', 'Cumulus' and 'Gijnlim' were characterised by the highest growth index, whereas 'Pacific Challenger' by the lowest (Fig. 2). A positive correlation was observed between plant growth index of tested cultivars in the preceding year and their yield in the successive vegetation period (Fig. 3).

Table 5. Early yield of 16 asparagus cultivars (mean of 2011-2013)

\begin{tabular}{|c|c|c|c|c|c|}
\hline \multirow[b]{2}{*}{ Cultivar } & \multicolumn{2}{|c|}{ Early yield } & \multirow[b]{2}{*}{ Cultivar } & \multicolumn{2}{|c|}{ Early yield } \\
\hline & $\mathrm{kg} \cdot \mathrm{ha}^{-1}$ & $\begin{array}{c}\text { Early yield as \% } \\
\text { of marketable yield }\end{array}$ & & $\mathrm{kg} \cdot \mathrm{ha}^{-1}$ & $\begin{array}{c}\text { Early yield as \% } \\
\text { of marketable yield }\end{array}$ \\
\hline Gijnlim & $3210 a^{*}$ & 50.6 & Ercole & $2080 \mathrm{~b}-\mathrm{e}$ & 46.8 \\
\hline Cumulus & $3090 \mathrm{ab}$ & 54.1 & Guelph Millennium & $2160 \mathrm{~b}-\mathrm{e}$ & 49.8 \\
\hline Mondeo & $3050 \mathrm{ab}$ & 54.5 & White Angel & $1810 \mathrm{c}-\mathrm{e}$ & 49.7 \\
\hline HP 149 & $2770 a-c$ & 51.8 & Н 666 & $2050 \mathrm{~b}-\mathrm{e}$ & 48.2 \\
\hline Avalim & 2580 a-d & 51.8 & Mo 2/12 & $1640 \mathrm{de}$ & 38.8 \\
\hline Ramires & $2700 a-c$ & 53.3 & NJ 953 & $2040 \mathrm{~b}-\mathrm{e}$ & 47.8 \\
\hline Victor & 2560 a-d & 48.4 & Pacific Challenger & $1390 \mathrm{e}$ & 47.6 \\
\hline Rapsody & $2140 \mathrm{~b}-\mathrm{e}$ & 47.0 & Pacific 2000 & $1410 \mathrm{e}$ & 47.5 \\
\hline
\end{tabular}

*Means followed by the same letter do not differ at $\mathrm{p}=0.05$ according to Newman-Keuls test

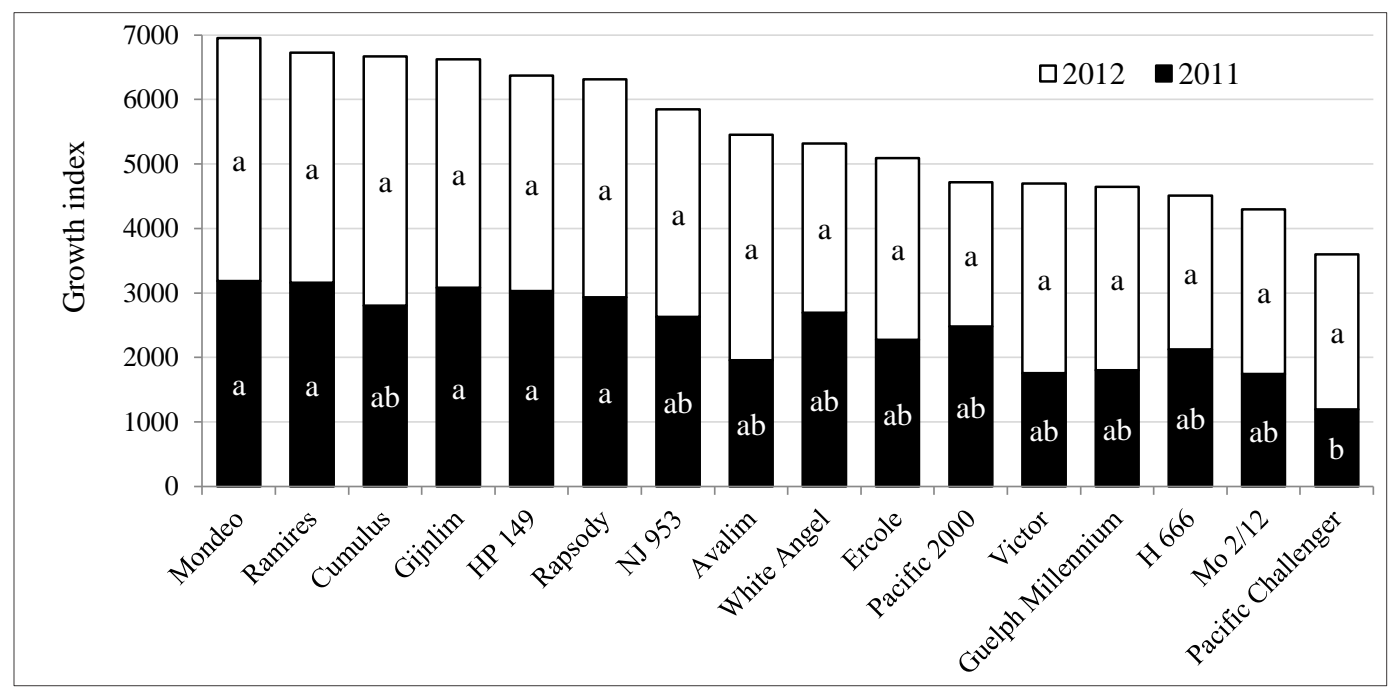

Means followed by the same letter do not differ at $\mathrm{p}=0.05$ according to Newman-Keul's test

Fig. 2. Growth index of 16 asparagus cultivars (2011 and 2012) 


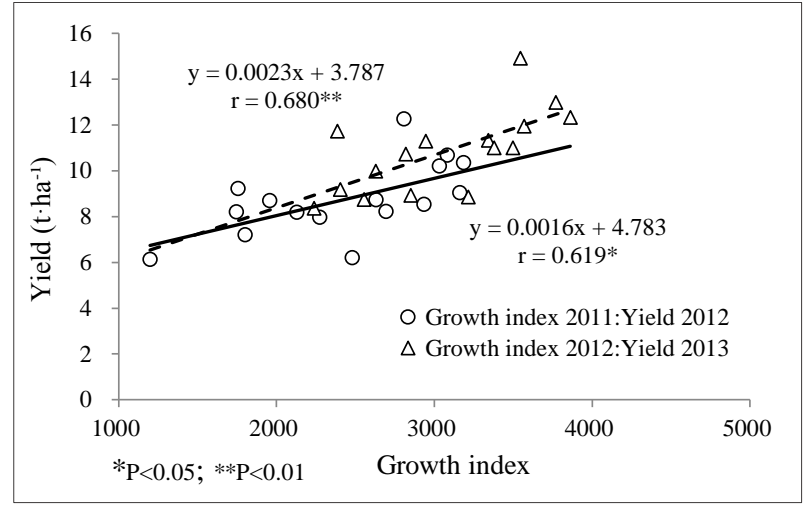

Fig. 3. Correlation between summer stalks growth index of sixteen cultivars in 2011 and 2012 and their total yield in 2012 and 2013

\section{CONCLUSIONS}

1. Cultivars 'Gijnlim', 'Cumulus' and 'Mondeo' were characterised by the highest total and marketable yields, whereas 'Pacific Challenger' and 'Pacific 2000' by the lowest.

2. 'Cumulus' produced spears of the greatest mean weight, while 'Pacific 2000' and 'NJ953' of the smallest.

3. The highest early yield was observed in 'Gijnlim' and slightly lower in 'Cumulus' and 'Mondeo' while the lowest in 'Pacific 2000' and 'Pacific Challenger'.

4. Growth index of tested cultivars in the previous year was found to be positively correlated with the yield in the following year.

\section{Acknowledgement}

The authors would like to express the sincere thanks to the Ministry of Science and Higher Education of Poland providing partial support for this study, which belonged to a part of the project 'NN 310095036 '.

\section{REFERENCES}

Araki H., Sarwar A.K.M.G., Nakano H., Takamushi S., Ichikawa S., Jishi T., Hoshino Y. 2012. Biomass production and yield of recent asparagus cultivars in snow cover region, Hokkaido, Japan: $3^{\text {rd }}$ IACT Report. Acta Hort. 950: 195-199.

Benson B. 2002. Second international asparagus cultivar trial final report. Acta Hort. 589: 159-166.
Benson B.L. 2008. 2005 update of the world's asparagus production areas, spear utilization, yields and production period. Acta Hort. 776: 495-507.

Blumenfield D.K., Meinken K.W., Le Compte S.B. 1961. A field study of asparagus growth. Proc. Am. Soc. Hortic. Sci. 77: 386-392.

Bouwkamp J.C., Mc Cully J.E. 1975. Effects of simulated and no-selective mechanical harvesting on spear emergence of Asparagus officinalis L. Scientia Horticulturae 3(2): 157-162. DOI: 10.1016/0304-4238(75)90022-9.

Cermeňo P., Ortega F.R., Calado S., Rubio V. 2008. Performance of green and white asparagus cultivars in southern Spain. Acta Hort. 776: 339-344.

Dean B.B. 1999. The effect of temperature on asparagus spear growth and correlation of heat units accumulated in the field with spear yield. Acta Hort. 479: 289-296.

Drost D. 2002. Asparagus cultivar trials in Utah. Acta Hort. 589: 167-171.

González M.I. 2008. Preliminary results of the third IACT at Chillán, Chile. Acta Hort. 776: 345-350.

González M.I. 2012. Results of Third International Asparagus Cultivar Trial at Chillán. Acta Hort. 950: 109-115.

Jinsong Y. 2002. Primary report of the Second International Asparagus Varieties Estimate Trials. Acta Hort. 589: 173-180.

Knaflewski M. 1994. Yield prediction of asparagus cultivars on the basis of summer stalk characteristics. Acta Hort. 371: 161-168.

Knaflewski M., Zaworska A., Chen W. 2011. Aktualności w uprawie szparaga. XVII Konferencja Szparagowa, Sielinko: 42-47. [in Polish]

Moon D.M. 1976. Yield potential of Asparagus officinalis L. New Zealand Journal of Experimental Agriculture 4: 435-438. DOI: 10.1080/03015521.1976.10425913.

Mulder J.H., Lavrijsen P. 2008. First results of the "Third international asparagus cultivar trial" planted in Horst, the Netherlands. Acta Hort. 776: 367-372.

Nichols M. 1997. First international asparagus cultivar trial (abstract). Acta Hort. 479: 195.

Nichols M.A., Woolley D.J. 1985. Growth studies with asparagus. Proceedings of the 6th International Asparagus Symposium, Guelph, 5-9 August 1985, pp. 287-297.

Paschold P.J., Artelt B., Hermann G. 2008. Comparison of white asparagus cultivars (Asparagus officinalis) in Germany. Acta Hort. 776: 379-386. 
Rodkiewicz T. 2011. Yielding of green asparagus cultivated on a medium heavy soil. Acta Sci. Pol., Hortorum Cultus. 10(3): 175-186.

Wilson D.R., Cloughley C.G. Sinton S.M. 1999. Model of the influence of temperature on the elongation rate of asparagus spears. Acta Hort. 479: 297-304.
Zhu Q.J., Chen L.L., Sun X., Zhang Q., Knaflewski M., Krzesiński W. 2013. Evaluation of adaptability of 28 green asparagus cultivars. Agricultural Science \& Technology 2: 235-242. 